\title{
Out-of-pocket and informal payments in Iran's health care system: A systematic review and meta-analysis
}

\author{
Seyed Abbas Mirabedini ${ }^{1}$, Seyed Mohammad Esmaeil Fazl Hashemi ${ }^{1}$, Ali Sarabi Asiabar ${ }^{1}$, \\ Aziz Rezapour ${ }^{1}$, Saber Azami-Aghdash ${ }^{2}$, Hassan Hosseini Amnab ${ }^{1 *}$

\section{Abstract}

Background: Out-of-pocket and informal payments are considered as 2 most important topics for equity in health care financing. Therfore, this study was conducted to systematically review and meta-analyze the status of these payments in Iran's health care system.

Methods: Required data were collected through searching the following key terms: "Unofficial", "Informal Payment", "Iran", "Health Financing", "Health expenditure", and "Out-of-pocket" on Scopus, PubMed, IranMedex, SID, and Google Scholar databases. After extracting and screening previous studies, data were collected from the articles using PRISMA pattern. To perform the metaanalysis, Comprehensive Meta-Analysis (CMA: 2) software was used.

Results: A total of 15 studies were entered in this review. Overall, the rate of out-of-pocket payments was estimated to be $50 \%(95 \%$ CI: $45-57 \%)$. A significant correlation was found between gender and the rate of out-of-pocket payments $(p \leq 0.05)$. Moreover, the overall rate of informal payments was found to be $35 \%$. Most of the informal payments were in form of cash, and the main reasons for informal payments were appreciating the staff and medical team as well as requests made by the hospital staff. Length of stay, marital status, employment status, income, and insurance coverage were key factors in the field of informal payments.

Conclusion: According to the results of the present study, out-of-pocket and informal payments are more prevalent in Iran. Considering the negative effects of these payments on the health care system, it is of prime importance to implement extensive interventions to reduce or even prevent these payments.

Keywords: Out-of-pocket, Informal payments, Health financing, Health system, Equity

Copyright@ Iran University of Medical Sciences

Cite this article as: Mirabedini SA, Esmaeil Fazl Hashemi SM, Sarabi Asiabar A, Rezapour A, Azami-Aghdash S, Hosseini Amnab H. Out-ofpocket and informal payments in Iran's health care system: A systematic review and meta-analysis. Med J Islam Repub Iran. 2017 (5 Oct);31:70. https://doi.org/10.14196/mjiri.31.70

\section{Introduction}

Many factors have raised health costs in recent years. The most significant factors are technological revolution in the field of health services (1), higher level of people's awareness, hygienic expectations, and high inflation rate in the health care sector compared to other economic sectors (2).

\section{Corresponding author: Hassan Hosseini Amnab, hhoseinia@yahoo.com}

1. Health Management and Economics Research Center, Iran University of Medical Sciences, Tehran, Iran.

2. Tabriz Health Services Management Research Center, Tabriz University of Medical Sciences, Tabriz, Iran.
Health expenditures reduce families' productivity, as the most important factor in national production by decreasing savings and allocating less income to other expenditures such as appropriate food and education, which have an undeniable influence on children as human capital accumulation. Therefore, the negative influence of a fi-

\section{$\uparrow$ What is "already known” in this topic:}

About $55 \%$ of the health system's resources are supplied by families' out-of-pocket payment. The average out-of-pocket expenditures for health is $24 \%$ in the world, however, this percentage reaches up to $50 \%$ in low-income countries. Studies have indicated an increase in informal payments worldwide, especially in countries with low and average incomes.

\section{$\rightarrow$ What this article adds:}

The amount of out-of-pocket payments was $50 \%$ in total. The amount of informal payments was around $35 \%$. Cash payments were the most common type of informal payments. Appreciating the efforts of hospital staff, physicians, and clerks' requests were the main factors in informal payments. Hospitalization period, marital and employment status, income level, and insurance coverage could be mentioned among the main influential factors in informal payments across different studies. 
nancial system's malfunction in health care sector can be considered in the process of capital accumulation and a society's future economic development (3).

Despite all the considered measures, supplying finances for health services in countries that have low- and middleincomes relies mainly on out- of- pocket payments and a relative lack of prepayment mechanisms such as tax or health insurance. One of the unpleasant consequences of this financial supply mechanism is imposing high expenses on families, while they are suffering from diseases (3). Out- of- pocket expenses can be defined as any kind of direct payments for the health expenditures when receiving health care services, and it is also the weakest and most unfair payment mechanism for health care. This mechanism, with respect to risk protection and justice, is regarded as the worst financial supply mechanism and results in the most financial risks for individuals (4).

In defining medical poverty trap, Whitehead et al. (2001) stated that "An increase in out- of- pocket payments for public and private health care services has pushed many families towards poverty and has intensified the poverty of those families who have already been in a poor state." (5). The average out- of- pocket expenditures for health is $24 \%$ in the world, but this percentage reaches up to $50 \%$ in low-income countries (6). According to the studies conducted on Iran's National Health Accounts, $55 \%$ of the health system's resources are supplied by families' out-of-pocket payment, while they are suffering from diseases (7). Based on what has explicitly been mentioned in Article 34 of the Fifth National Development Plan, to reach justice index in health, people's out-ofpocket payments for health care should reach up to $30 \%$ of the total expenditures, and people's fair access to health services should be guaranteed (8).

From economic experts' point of view, informal payments are a kind of out- of- pocket payment and can be defined as payments that are paid to individuals or health care organizations, which are not part of the formal payment channels and can be made in the form of cash, presents, gratuitous aids, and etc. These payments are also the main resource of financial supply for health care services in countries with low- and average- incomes, which can cause critical obstacles in modifying the health system (912). The results of the conducted studies revealed an increase in informal payments worldwide, especially in countries with low- and average- incomes (13-16). The range of changes in the amount of informal payments is very wide, from $2 \%$ in Peru to up to $96 \%$ in Pakistan (17).

Because in the recent years in Iran supporting families for high expenditures of health care as a favorable goal has been unanimously accepted as a policy of the health system (18), it is essential to collect detailed and scientific information about out- of- pocket payments and informal payments, which are 2 important issues in financially supporting the health system. This information provides the health policymakers and planners with valuable information on the expenditures imposed on families due to health expenditures and the poverty because of it. Although some studies have been conducted on out- ofpocket payments and informal payments in Iran's health system in recent years, these studies could not provide precise, sufficient, and clear information to planners and policymakers of the health system. Thus, it seems that collecting and scientifically analyzing the results of the conducted studies and presenting a clear image of out- ofpocket payments and informal payments status can remarkably help the health system's planners and policymakers. Therefore, the present study was conducted to systematically review and meta-analyze out- of- pocket payments and informal payments in Iran's health system.

\section{Methods}

This systematic review was designed and implemented in 2016 and took an advantage of the systematic review approach adapted from a book named "systematic review for supporting evidence-based medicine" (19).

\section{Searching strategies}

The required data were collected from Scopus, PubMed, IranMedex, SID and Google scholar databases using the following key terms and their Persian equivalents: "Iran", "Finance", "expenditure", "out of pocket", "out-of-pocket payment *' and "informal payment *'. The related articles were published during 2000 and 2016. To find more published articles, hand searching was used after searching the databases. After excluding some studies that were weakly related to the goals of this review and selecting the main articles, the reference lists of the articles was checked once again to ensure identification reliability. In addition, some experts in the health system's financial supply and health economy sectors were consulted.

\section{Inclusion and exclusion criteria}

The criteria for including the studies were as follow: referring to at least one aspects of out- of- pocket payments or informal payments in Iran's health system; and studies conducted in the society and hospitals (Those studies that investigated out- of- pocket payments or informal payments in primary health care were omitted.).

Excluding criteria were as follow: non-English and Persian studies; the articles presented at seminars; and those which had investigated out- of- pocket payments and informal payments in Iran's health system before and after the Health Revolution Plan.

\section{Evaluation}

All the studies were evaluated after being extracted from data bases by 2 evaluators using strengthening the Reporting of Observational studies in Epidemiology (STROBE) check list, with 22 items $(21,22)$. This check list was selected because of its usability for evaluating observational studies, its translation into Persian, and its validation in Persian (20). In this study, those studies that paid no attention to at least half of these items (11 out of 22 items) were excluded.

\section{Data extraction}

To extract data, at first, 3 data extraction forms were manually designed using the Word software: the first one was for the studies, which had reported the amount of out- 
of- pocket payments; the second one for those that had reported informal payments; and the third one for the other studies that had not reported out- of- pocket payments and informal payments. At first, the data of 3 studies were extracted to design these forms, and then, the flaws and problems in the primary forms were fixed.

Extracted information in the first form was as follows: author/ year, city/ region, data collection year, participants/ medical problem/ medical service, Health center type, sample size, (\%), out- of- pocket, risk factors.

Extracted information in the second form was as follows: author/ year, city/ region, data collection year, participants/ medical problem/ medical service, health center type, sample size, $(\%)$, informal payment, types of informal payment, causes of informal payment, and risk factors of informal payment.

Extracted information in the third form was as follows: author/ year, aim of the study, type of the study, participants, and overall results.

\section{Data analysis methods}

Meta-analysis of the statistical methods with fixed models was used to calculate the amount of out- of- pocket payments and informal payments. Comprehensive MetaAnalysis software (CMA: 2) was used to perform metaanalysis. Forest plot graphs were applied to report the results in which the size of each square shows sample volume, and the lines on each side of the squares show $95 \%$ confidence interval. For studies on out- of- pocket payments, the results were obtained according to the place of conducting the study (hospital or the society) by subgroup analysis. Q statistic and $\mathrm{I}^{2}$ index were used for heterogeneous assessment of the study results. In this study, the $\mathrm{I}^{2}$ was determined to be more than $50 \%$ for the studies' heterogeneity criterion.

\section{Results}

From the 129 articles found among data bases and other sources, 41 were excluded due to being common among different sources, 68 were disregarded after checking their titles and abstracts, and 5 were omitted after being checked completely. Finally, 15 articles ( 7 articles on outof- pocket payments, 5 on informal payments, and 3 on other studies) were used in this study (Fig. 1).

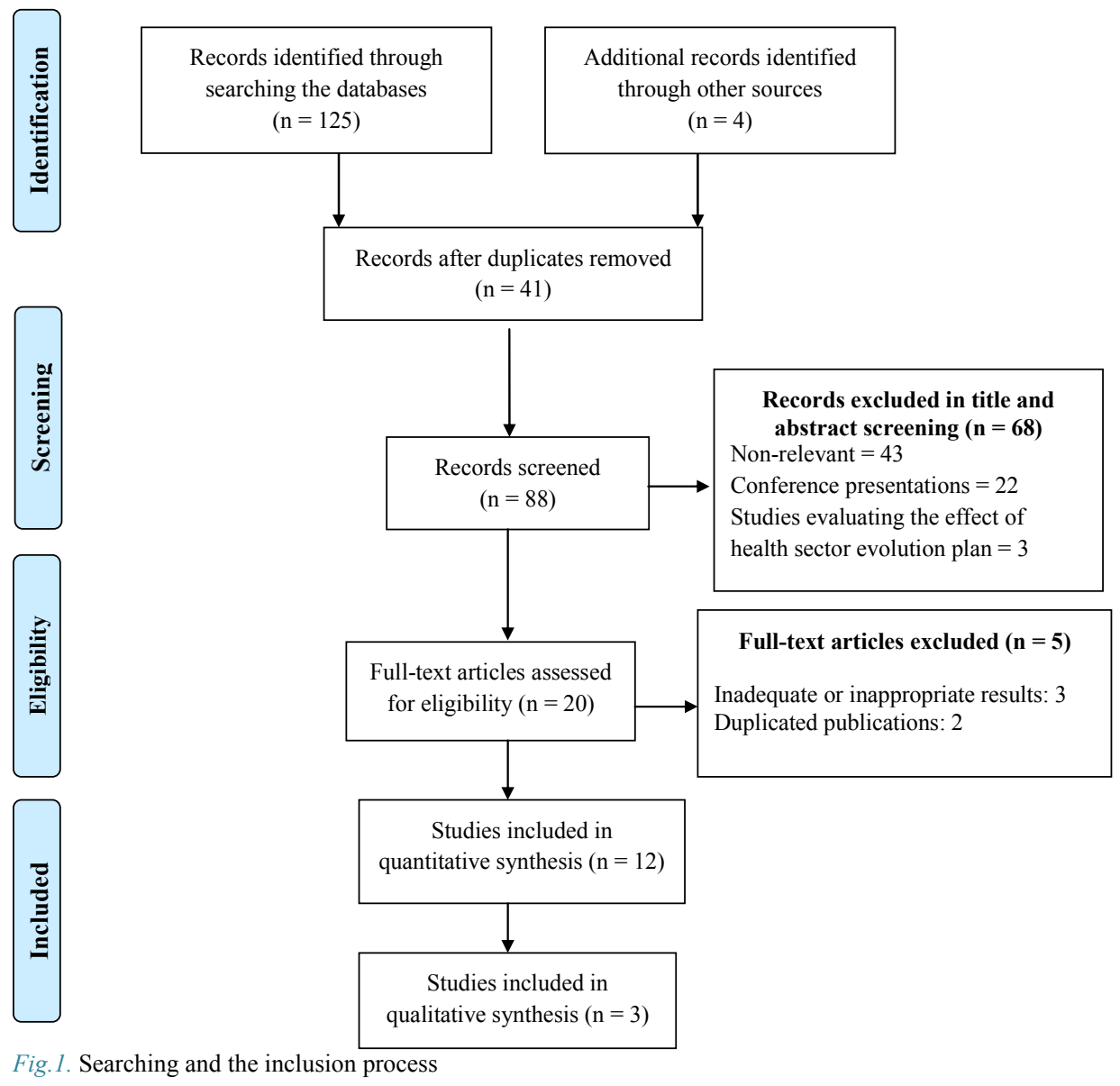


The specifications and information about the 15 investigated articles have been presented in Tables 1, 2, and 3 . The studies on out- of- pocket payments had been conducted in 5 cities of Tehran, Qazvin, Kurdistan, Gilan, and Tabriz; and the studies on informal payments were done in 4 cities of Tehran, Tabriz, Shiraz, and Urmia; and other studies had been conducted in Kerman ( 2 studies) and Tehran (1 study). Overall, some studies had only been performed in 8 cities of Iran.

The results of meta-analysis for out- of- pocket pay- ments revealed that this amount was about 50\% (95\% CI: 45-57) (Heterogeneity test: $\mathrm{Q}=7.41, \mathrm{df}=6, \mathrm{p}=0.28$, $\left.\mathrm{I}^{2}=19\right)$. The amount of out- of- pocket payments in the conducted studies in the society was estimated to be $56 \%$ (95\% CI: 49-65, Heterogeneity test: $Q=0.14, d f=2$, $\mathrm{p}=0.93, \mathrm{I}^{2}=0$ ). The amount of out- of- pocket payments in hospitals was estimated to be $41 \%$ (95\% CI: 33-50, Heterogeneity test: $\mathrm{Q}=1.01, \mathrm{df}=3, \mathrm{p}=0.79, \mathrm{I}^{2}=0$ ) (Fig. 2).

Out- of- pocket payment was mentioned as an important factor in only 2 studies conducted by Asefzadeh S, et al.

Table 1. Characteristics of included studies about out-of-pocket payments in Iran's health system

\begin{tabular}{|c|c|c|c|c|c|c|c|}
\hline Author/ year & City/ region & $\begin{array}{l}\text { Data collec- } \\
\text { tion year }\end{array}$ & $\begin{array}{l}\text { Participants/ medical prob- } \\
\text { lem/ medical service }\end{array}$ & Health center type & $\begin{array}{l}\text { Sample } \\
\text { size }\end{array}$ & $\begin{array}{l}\text { Out- of- } \\
\text { pocket }(\%)\end{array}$ & $\begin{array}{l}\text { Risk } \\
\text { factors }\end{array}$ \\
\hline $\begin{array}{l}\text { Yavangi M, } \\
\text { et al. } 2013(9)\end{array}$ & Tehran & 2009 & Obstetrical complications & $\begin{array}{l}\text { Teaching } \\
\text { hospitals }\end{array}$ & 1172 & 37.6 & - \\
\hline $\begin{array}{l}\text { Asefzadeh S, } \\
\text { et al. } 2014 \text { (1) }\end{array}$ & Qazvin & 2011 & $\begin{array}{c}\text { Outpatient diagnostic } \\
\text { services }\end{array}$ & $\begin{array}{l}\text { Teaching } \\
\text { hospitals }\end{array}$ & 800 & 45.3 & Gender \\
\hline $\begin{array}{l}\text { Gharibi F, et al. } \\
2013 \text { (10) }\end{array}$ & Kurdistan & 2010 & households & $\begin{array}{c}\text { Health care } \\
\text { services and } \\
\text { health equipment }\end{array}$ & 1518 & 55 & - \\
\hline $\begin{array}{l}\text { Keshavarz A, } \\
\text { et al. 2011(11) }\end{array}$ & Qazvin & 2009 & Urban households & $\begin{array}{c}\text { Health care } \\
\text { services and } \\
\text { health equipment }\end{array}$ & 384 & 59.7 & - \\
\hline $\begin{array}{l}\text { Marzban S, et al. } \\
2015 \text { (2) }\end{array}$ & Tehran & 2014 & Outpatient imaging services & $\begin{array}{l}\text { Teaching } \\
\text { hospitals }\end{array}$ & 100 & 32 & Gender \\
\hline $\begin{array}{l}\text { Semnani S, } \\
\text { Keshtkar AA. } \\
2003 \text { (12) }\end{array}$ & Gorgan district & 2002 & Urban households & $\begin{array}{c}\text { Health care } \\
\text { services and } \\
\text { health equipment }\end{array}$ & 1014 & 57 & - \\
\hline $\begin{array}{l}\text { Hassan Nejad N, } \\
2012 \text { (13) }\end{array}$ & Tabriz & 2009 & $\begin{array}{c}\text { Hospitalized diabetic } \\
\text { Patients }\end{array}$ & $\begin{array}{l}\text { Teaching } \\
\text { hospitals }\end{array}$ & 94 & 47.2 & - \\
\hline
\end{tabular}

Table 2. Characteristics of the included studies about informal payments in Iran's health system

\begin{tabular}{|c|c|c|c|c|c|c|c|c|c|}
\hline Author/ year & $\begin{array}{l}\text { City/ } \\
\text { region }\end{array}$ & $\begin{array}{c}\text { Data } \\
\text { collection } \\
\text { year }\end{array}$ & $\begin{array}{l}\text { Participants/ } \\
\text { medical prob- } \\
\text { lem/ medical } \\
\text { service }\end{array}$ & $\begin{array}{l}\text { Health } \\
\text { center } \\
\text { type }\end{array}$ & $\begin{array}{l}\text { Sample } \\
\text { size }\end{array}$ & $\begin{array}{c}\text { Informal } \\
\text { payment } \\
(\%)\end{array}$ & $\begin{array}{l}\text { Types of } \\
\text { informal } \\
\text { payment }\end{array}$ & $\begin{array}{l}\text { Causes of } \\
\text { informal } \\
\text { payment }\end{array}$ & $\begin{array}{c}\text { Risk factors } \\
\text { of informal } \\
\text { payment }\end{array}$ \\
\hline $\begin{array}{l}\text { Ghiasipour } \\
\text { M, et al. } \\
\text { 2011(3) }\end{array}$ & Tehran & 2009 & $\begin{array}{c}\text { Discharged } \\
\text { patients }\end{array}$ & $\begin{array}{l}\text { Teaching } \\
\text { hospitals }\end{array}$ & 300 & 21 & $\begin{array}{c}\text { Cash (88.8), } \\
\text { gift (1.6), } \\
\text { Commodity } \\
(9.5)\end{array}$ & $\begin{array}{l}\text { Appreciation } \\
\text { (55.6), to be } \\
\text { forced to } \\
\text { (28.6), hope } \\
\text { to get more } \\
\text { services } \\
(9.5), \text { staff } \\
\text { request }(6.5)\end{array}$ & $\begin{array}{c}\text { Length of } \\
\text { stay, marital } \\
\text { statues }\end{array}$ \\
\hline $\begin{array}{l}\text { Vahidi RGH, } \\
\text { Saadati M. } \\
\text { 2011(5) }\end{array}$ & Tabriz & 2010 & $\begin{array}{l}\text { Cardiac pa- } \\
\text { tients }\end{array}$ & $\begin{array}{l}\text { Teaching } \\
\text { hospitals }\end{array}$ & 50 & 10 & - & $\begin{array}{l}\text { Staff request } \\
(80) \text {, appre- } \\
\text { ciation }(20)\end{array}$ & - \\
\hline $\begin{array}{l}\text { Jafari A, et al. } \\
2015(4)\end{array}$ & Shiraz & 2012 & $\begin{array}{c}\text { Discharged } \\
\text { patients }\end{array}$ & $\begin{array}{l}\text { Teaching } \\
\text { hospitals }\end{array}$ & 201 & 20 & $\begin{array}{c}\text { Cash (39), } \\
\text { gift (39), } \\
\text { Commodity } \\
(9.8), \\
\text { Commitment } \\
(12.2)\end{array}$ & - & $\begin{array}{l}\text { Employment } \\
\text { status, pri- } \\
\text { mary insur- } \\
\text { ance, }\end{array}$ \\
\hline $\begin{array}{l}\text { Meskarpour- } \\
\text { Amiri M, et } \\
\text { al. } 2016(14)\end{array}$ & Tehran & 2014 & $\begin{array}{c}\text { Discharged } \\
\text { patients }\end{array}$ & $\begin{array}{l}\text { Teaching } \\
\text { hospitals }\end{array}$ & 480 & 48 & - & - & $\begin{array}{c}\text { Older peo- } \\
\text { ple, members } \\
\text { of small and } \\
\text { wealthier } \\
\text { families, } \\
\text { employed, } \\
\text { under cover- } \\
\text { age of only } \\
\text { basic medi- } \\
\text { cal insurance }\end{array}$ \\
\hline $\begin{array}{l}\text { Khodamoradi } \\
\text { A, et al. } \\
2015(15)\end{array}$ & Urmia & 2013 & $\begin{array}{c}\text { Discharged } \\
\text { patients }\end{array}$ & $\begin{array}{l}\text { Teaching, } \\
\text { private, } \\
\text { and social } \\
\text { security } \\
\text { hospitals }\end{array}$ & 265 & 30 & - & - & $\begin{array}{c}\text { Type of } \\
\text { hospital, } \\
\text { place of } \\
\text { settlement, } \\
\text { treatment } \\
\text { procedure } \\
\text { and income }\end{array}$ \\
\hline
\end{tabular}




\begin{tabular}{|c|c|c|c|c|}
\hline $\begin{array}{l}\text { Author, } \\
\text { year }\end{array}$ & $\begin{array}{c}\text { Aim of the } \\
\text { study }\end{array}$ & $\begin{array}{c}\text { Type of the } \\
\text { study }\end{array}$ & Participants & Overall results \\
\hline $\begin{array}{l}\text { Amir- } \\
\text { esmaeil } \\
\text { et al. } \\
2013(6)\end{array}$ & $\begin{array}{l}\text { Causes of } \\
\text { informal } \\
\text { payments in } \\
\text { hospitals of } \\
\text { Kerman } \\
\text { city }\end{array}$ & $\begin{array}{c}\text { Qualitative } \\
\text { study }\end{array}$ & $\begin{array}{l}30 \text { patients, } 12 \\
\text { doctors, and } 3 \\
\text { policy makers }\end{array}$ & $\begin{array}{l}\text { Causes of informal payments from patients' point of view: } \\
\text {-Cultural factors including gratitude and appreciation, the importance of health } \\
\text { compared to other issues, existence of the culture of complimenting, and patients' } \\
\text { unawareness } \\
\text {-Quality-related factors including better and more famous doctors, receiving better } \\
\text { health services, fear of stopping the treatment, by passing the waiting list, unwill- } \\
\text { ingness of medical students to work } \\
\text {-Legal factors including weakness of regulations and inefficient system of dealing } \\
\text { with complaints }\end{array}$ \\
\hline
\end{tabular}

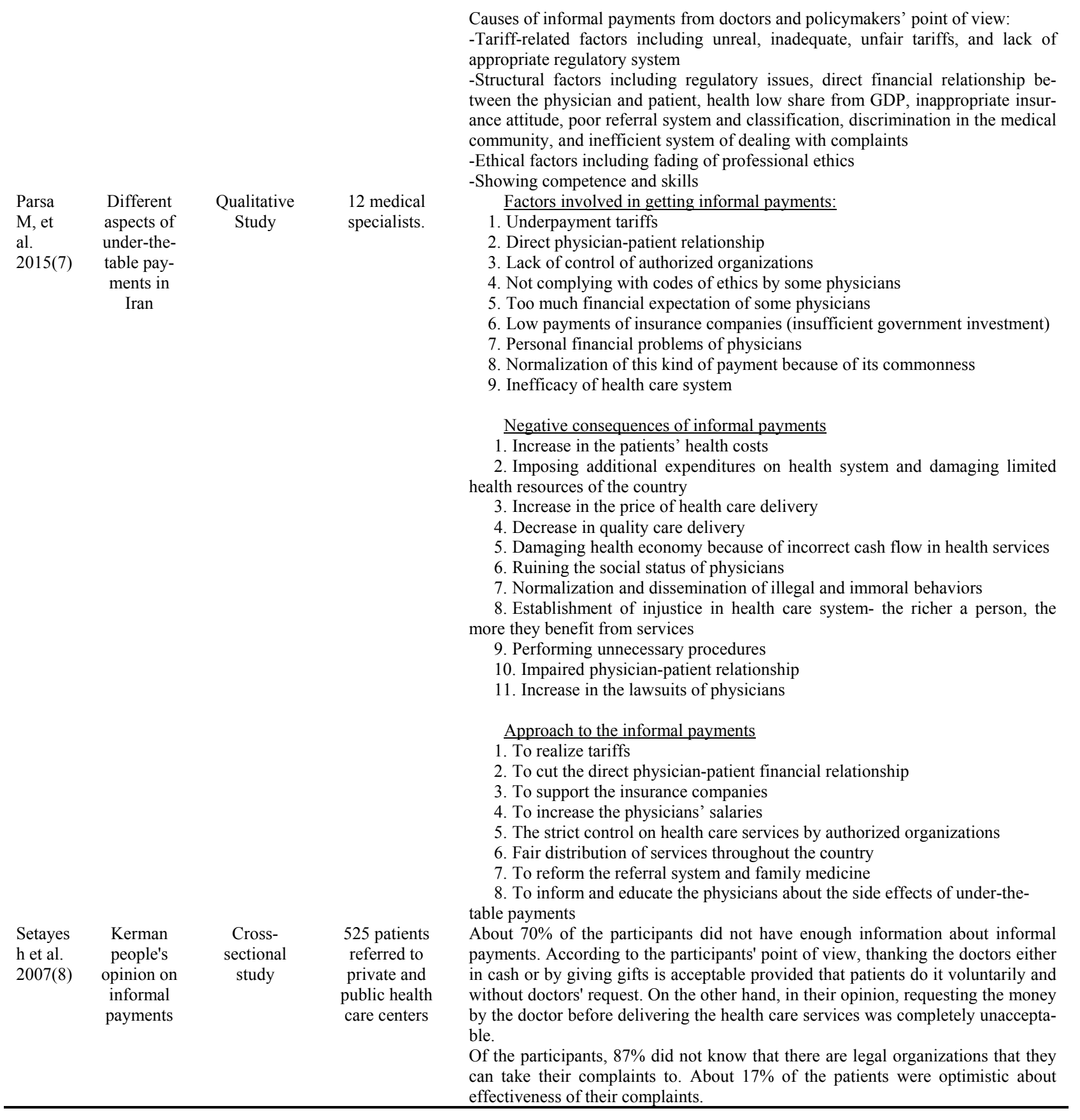

2014 (23) and Marzban S, et al. 2015 (24); and in both of these studies, there was a significant relationship between sex and out- of- pocket payment; ie, males had more outof- pocket expenses compared to females.
Meta-analysis of informal payments revealed that the total amount of out- of- pocket expenses was 35\% (95\%CI: 26-47, Heterogeneity test: $\mathrm{Q}=6.3, \mathrm{df}=4, \mathrm{p}=0.17$, $\mathrm{I}^{2}=37.3$ ) (Fig. 3). 


\begin{tabular}{|c|c|c|c|c|c|c|c|c|}
\hline \multirow{2}{*}{$\frac{\text { Group by }}{\text { setting }}$} & \multirow[t]{2}{*}{ Study name } & \multicolumn{5}{|c|}{ Statistics for each study } & \multicolumn{2}{|c|}{ Event rate and $95 \% \mathrm{Cl}$} \\
\hline & & $\begin{array}{l}\text { Event } \\
\text { rate }\end{array}$ & $\begin{array}{l}\text { Lower } \\
\text { limit }\end{array}$ & $\begin{array}{l}\text { Upper } \\
\text { limit }\end{array}$ & Z-Value & $\mathrm{p}$-Value & & \\
\hline hospital & Yavangi M, et al:2013 & 0.038 & 0.028 & 0.050 & -21.116 & 0.000 & & \\
\hline hospital & Asefzadeh S, et al:2014 & 0.045 & 0.033 & 0.062 & -17.929 & 0.000 & & \\
\hline hospital & Marzban S, et al:2015 & 0.032 & 0.011 & 0.091 & -6.001 & 0.000 & & \\
\hline hospital & Hassan Nejad N, 2012 & 0.047 & 0.019 & 0.114 & -6.178 & 0.000 & & \\
\hline hospital & & 0.041 & 0.033 & 0.050 & -28.991 & 0.000 & & A \\
\hline households & Gharibi F, et al: 2013 & 0.055 & 0.045 & 0.068 & -25.260 & 0.000 & & \\
\hline households & Keshavarz A, et al:2011 & 0.060 & 0.040 & 0.088 & -12.800 & 0.000 & & - \\
\hline households & Semnani S, Keshtkar AA:200 & 00.057 & 0.044 & 0.073 & -20.716 & 0.000 & & \\
\hline households & & 0.056 & 0.049 & 0.065 & -35.085 & 0.000 & & 1 \\
\hline Overall & & 0.050 & 0.045 & 0.057 & -45.444 & 0.000 & & 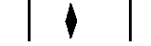 \\
\hline
\end{tabular}

Fig. 2. Meta-analysis of out-of-pocket payments in Iran's health care system

Study name

$\begin{array}{lcccccc} & \begin{array}{c}\text { Event } \\ \text { rate }\end{array} & \begin{array}{c}\text { Lower } \\ \text { limit }\end{array} & \begin{array}{c}\text { Upper } \\ \text { limit }\end{array} & \text { Z-Value } & \text { p-Value } \\ \text { Ghiasipour M, et al:2011 } & 0.021 & 0.010 & 0.045 & -9.542 & 0.000 \\ \text { Vahidi RGH, Saadati M:2011 } & 0.010 & 0.001 & 0.141 & -3.233 & 0.001 \\ \text { Jafari A, et al:2015 } & 0.020 & 0.008 & 0.052 & -7.725 & 0.000 \\ \text { Meskarpour-Amiri M, et al:2016 } & 0.048 & 0.032 & 0.071 & -13.991 & 0.000 \\ \text { Khodamoradi A, et al:2015 } & 0.030 & 0.015 & 0.059 & -9.653 & 0.000 \\ & 0.035 & 0.026 & 0.047 & -21.064 & 0.000\end{array}$

\section{Event rate and $95 \% \mathrm{Cl}$}

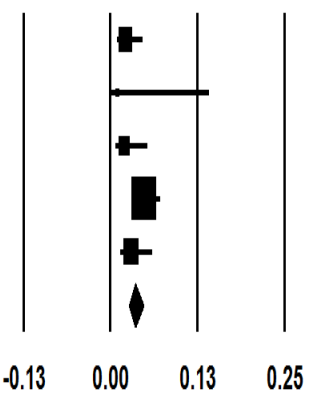

Fig. 3. Meta-analysis of informal payments in Iran's health care system

In both studies of Ghiasipour M, et al. 2011 (25) and Jafari A, et al. 2015 (26), the type of informal payments was mentioned, and in both studies cash payments were the most common type. Giving gifts and commodities were among the other types of informal payments. In a study conducted by Ghiasipour M, et al. 2011 (25), appreciating the efforts of hospital personnel and physicians was the main reason for informal payments. In contrast, in another study done by Vahidi RGH and Saadati M 2011(27), clerks' request was mentioned as the main factor in informal payments.

Hospitalization period, marital and employment status, income level, and insurance coverage can be mentioned among the influential factors in informal payments found in different studies.

In a study conducted by Amir Esmaili et al. (2013) (28), the most important reasons behind informal payments from patients, physicians, and policymakers' point of view were found to be cultural factors, quality-related factors, legal, tariff-related, structural and ethical factors as well as showing skills and competency. In a study done by Parsa et al. (2005) (29), effective factors in informal payments, the negative consequences of informal payments, and common approaches in informal payments were investi- gated. The results of another study conducted by Setayesh et al. (2007) (30) on the reasons behind informal payments and based on a survey of 525 people in Kerman, revealed that around $70 \%$ of the participants had sufficient information about informal payments (bribes) (Table 3).

\section{Discussion}

The results of this study revealed that the amount of outof- pocket payments was about $50 \%$. In the conducted studies, sex had a significant relationship with out- ofpocket payments; eg, males had more out- of- pocket expenses. The amount of informal payments was estimated to be around $35 \%$. Cash payments were the most common type of informal payments. Appreciating the efforts of hospital staff and physicians and clerks' requests were the main factors in informal payments. Hospitalization period, marital and employment status, income level, and insurance coverage can be mentioned among the main influential factors in informal payments found in different studies.

According to the results of the study, only in 8 cities/provinces of Iran some studies had been done on outof- pocket payments and informal payments. In other words, out- of- pocket payments and informal payments 
data in the other 23 provinces of Iran have not been scientifically investigated. Given the importance and sensitivity of the matter and great cultural and socioeconomic differences in different regions of the country, it is highly important that the local data be scientifically and precisely calculated and reported to be used in decision-making and planning.

According to the results of the reviewed studies, the amount of out- of- pocket payments was 50\%; this amount is $8.2 \%$ in China (38), 3.4\% in Cambodia (39), and $1.7 \%$ in Vietnam (40). Out- of- pocket payment in countries with high income is generally about $24 \%$, but in countries with low- and average- incomes, it is more than 50\% (41). According to the studies done on Iran's National Health Accounts, $55 \%$ of the health system's resources are supplied by families' direct payment, when they are sick (7), which is convergent with the results of the present study. Since it is explicitly mentioned in Article 34 of the Fifth National Development Plan to accomplish justice index in health, people's direct payments for health care must reach to $30 \%$ of the total expenditures at most, and people's fair access to health services must be guaranteed (8). Therefore, the required financial support and the other measures and planning should be provided. Moreover, the calculated $50 \%$ for out- of- pocket payment in this study was based on the studies conducted before the health revolution plan. On May 15, 2014, the Ministry of Health and Medical Education sent the health system's revolution plan agenda to all medical universities. This agenda included 7 general plans, whose first plan was reducing the amount of payments for hospitalized patients in Health and Medical Education Ministry hospitals (42, 43). By performing such agenda in the Health and Medical Education Ministry hospitals, the amount of out- of- pocket payments has decreased significantly. The results of the study done by Piroozi et al. (2016) in Kurdistan revealed that after performing the health system's revolution plan, the percentage of out- of- pocket payments in hospital bills has significantly dropped (44). Furthermore, the results of another study performed by Nahid and Shaghayaegh (2015) in Isfahan revealed that the Health System Revolution Plan has reduced out- of- pocket payments in Isfahan's governmental hospitals up to $17.3 \%$ (45). In addition, the results of another study conducted by Sarkhanloo et al. (2016) revealed that the health system's reform plan has managed to significantly reduce out- ofpocket payments for patients, who are suffering from cancer (46). Because to assess the efficiency and accomplishments of this great national plan some valid data about the time before starting is required, the data of the present study can be used as a valid and basic source to compare the previous status of the health system before this plan.

Given the results of some studies, the amount of informal payments was estimated to be up to $35 \%$. In a study performed by Liaropoulos et al. (2008) in Greece, the amount of informal payments given to physicians, nurses, and other clerks was $36 \%, 11 \%$, and $8.5 \%$, respectively (47).

In addition, in another study done by Ozgen et al.
(2010) in Turkey, 31\% of the patients had an experience of out- of- pocket payments (48). The results of the conducted studies revealed the increasing trend of informal payments around the world, especially in countries with low- and middle- incomes (13-16). The range of the amount of out- of- pocket payments is so wide, from $2 \%$ in Peru to up to $96 \%$ in Pakistan (17). Among the unpleasant effects and consequences of informal payments, some of the most important ones are changes in government's investment priorities, inefficiency of the health system, an increase in corruption, and a decrease in trust and the system's clarity, justice in health access, taking an advantage of services, quality of services, building motivation among service providers, increasing expenditures, presenting wrong information about treatment expenditures, and patients' share of payments (14, 15, 49-53). Therefore, it is highly important to take the necessary measures to reduce and prevent such payments. Informing the public, increasing the received payments of health service providers, understanding the tariffs, exerting more control over hospitals, and disconnecting the financial relationship between patients and health service providers are among the measures that can be taken by managers and policymakers. Lack of sufficient data on informal payments and effective factors about out- of- pocket and informal payments can be mentioned as the most important limitations of this study, which restricted further analyses and discussions concerning the issue. It is recommended that researchers pay ample attention to the discussed matters in their future studies.

\section{Conclusion}

The results of the present study revealed that out- ofpocket payments and informal payments are among the strategic goals of the health system in Islamic Republic of Iran and most countries. Therefore, given the unpleasant effects and consequences of out- of- pocket payments and informal payments, it is of paramount importance to take fundamental measures to reduce and prevent such expenses. Reinforcing and continuing the health revolution plan, instructing people, and restricting the direct financial relationship between patients and health service providers are among the most important solutions, which can be used by managers and policymakers.

\section{Conflict of Interests}

The authors declare that they have no competing interests.

\section{References}

1. Rezapour A, Ebadifard Azar F, Azami Aghdash S, Tanoomand A, Ahmadzadeh N, Sarabi Asiabar A. Inequity in household's capacity to pay and health payments in Tehran-Iran-2013. Med J Islam Repub Iran. 2015;29:245.

2. Folland S, Goodman A, Stano M. Economics of health and health care. 2006.

3. Rezapour A, Arabloo J, Tofighi S, Alipour V, Sepandy M, Mokhtari $\mathrm{P}$, et al. Determining Equity in Household's Health Care Payments in Hamedan Province, Iran. Arch Iran Med. 2016;19(7):480-7.

4. World Health Organization, Regional Committee for Eastern Mediterranean. The impact of health expenditure on household and options for alternative financing. Technical paper, EM/RC 51/4; 
July 2004.

5. Abul Naga R, Lamiraud K. Catastrophic Health Expenditure and Household Well-Being. 2009.

6. The impact of health expenditure on households and options for alternative financing. regional committee for the eastern mediterranean. 2004.

7. Majlis Research Center .National health accounts in 1380-1384. 5-12.

8. Ourth Five-Year Development Plan set. tehran: presidence, d.f.S.P.a.M.o, 2010.

9. Rezapour A, Ghaderi H, Azar FE, Larijani B, Gohari MR. Effects of Health Out-of-Pocket Payment on HouseHolds in Iran; Catastrophic and Impoverishment: Population Based Study in Tehran (2012). Life Sci J. 2013;10(3):1457-69

10. Chereches RM, Ungureanu MI, Sandu P, Rus IA. Defining informal payments in healthcare: a systematic review. Health policy (Amsterdam, Netherlands). 2013;110(2-3):105-14.

11. Kaitelidou D, Tsirona CS, Galanis PA, Siskou O, Mladovsky P, Kouli EG, et al. Informal payments for maternity health services in public hospitals in Greece. Health policy (Amsterdam, Netherlands). 2013;109(1):23-30.

12. Lindkvist I. Informal payments and health worker effort: a quantitative study from Tanzania. Health economics. 2013;22(10):1250-71.

13. Aboutorabi A, Ghiasipour M, Rezapour A, Pourreza A, Sarabi Asiabar A, Tanoomand A. Factors affecting the informal payments in public and teaching hospitals. Med J Islam Repub Iran. 2016;30:315

14. Kankeu HT, Ventelou B. Socioeconomic inequalities in informal payments for health care: An assessment of the 'Robin Hood' hypothesis in 33 African countries. Soc Sci Med (1982). 2016;151:173-86

15. Souliotis K, Golna C, Tountas Y, Siskou O, Kaitelidou D, Liaropoulos L. Informal payments in the Greek health sector amid the financial crisis: old habits die last. Eur J Health Econ. 2016;17(2):159-70.

16. Stepurko T, Pavlova M, Gryga I, Groot W. To pay or not to pay? A multicountry study on informal payments for health-care services and consumers' perceptions. Health Expect. 2015;18(6):2978-93.

17. Lewis M. Who is Paying for Health Care in Eastern Europe and Central asia.World Bank; 2000.

18. Vaez-mahdavi $\mathrm{m}$. The first measure of justice in Tehran. tehran: health deputy of municipality, 2009.

19. Khan SK, Kunz R, Kleijnen J, Antes G. Systematic reviews to support evidence-based medicine. Mazurek Melnyk B, editor2011.

20. Poorolajal J, Tajik P, Yazdizadeh B, Sehat M, Salehi A, Rezaei M, et al. Quality Assessment of the Reporting of Cohort Studies before STROBE Statement. Iran J Epidemilogy. 2009;5 (1):17-26.

21. von Elm E, Altman DG, Egger M, Pocock SJ, Gotzsche PC, Vandenbroucke JP. The Strengthening the Reporting of Observational Studies in Epidemiology (STROBE) statement: guidelines for reporting observational studies. Ann Intern Med. 2007;147(8):573-7.

22. von Elm E, Altman DG, Egger M, Pocock SJ, Gotzsche PC, Vandenbroucke JP. The Strengthening the Reporting of Observational Studies in Epidemiology (STROBE) statement: guidelines for reporting observational studies. PLoS Med. 2007;4(10):e296.

23. Asefzadeh S, Alijanzadeh M, Peyravian F. Out of pocket expenditures for outpatient clinics in teaching hospitals. Payesh 2014;13:267-76.

24. Marzban S, Rajaee R, Gholami S, Keykale MS, Najafi M. Study of Out-of-Pocket Expenditures for Outpatient Imaging Services in Imam-Khomeini Hospital in 2014. Electronic Physician. 2015;7(4):1183-9.

25. Ghiasipour M, Abolghasem P, Arab M, Mahmoodi M, Abutorabi A. The Analysis of Informal Payments Among Hospitals Covered Under Tehran University of Medical Sciences (TUMS) 2009. Hospital Quarterly 2011;10:1-14.

26. Jafari A, Ravangard R, Heidari F, Roshani M, Hadian M, Mohammadi M. Informal Payment in Health Settings: A Survey of Teaching Hospitals. Int J Hosp Res.. 2015;4(2):83-8.

27. Vahidi R, Saadati M. Determining the distribution of effective factors on out of pocket payment (formal and informal) in hospitalized cardiac patientsof Shahid Madani hospital and its side effects on the patient or companions-Iran-Tabriz 2010. Hospital.
2013;11(4):45-52.

28. Nekoeimoghadam M, Esfandiari A, Ramezani F, Amiresmaili M. Informal payments in healthcare: a case study of kerman province in iran. Int J Health Policy Manag. 2013;1(2):157-62.

29. Parsa M, Aramesh K, Nedjat S, Kandi MJ, Larijani B. Informal Payments for Health Care in Iran: Results of a Qualitative Study. Iran J Public Health. 2015;44(1):79-88.

30. Nekoeimoghadam M, Esfandiari A, Ramezani F, Amiresmaili M. Informal payments in healthcare: a case study of Kerman province in Iran. Int J Health Policy Manag. 2013;1(2):157-162

31. Yavangi M, Sohrabi M, Riazi S. Out of pocket payment for obstetrical complications: A cost analysis study in Iran. Int J Prev Med. 2013;4:1296?303.

32. Gharibi F, Heidari A, Zarei M. Percentage of out-of-pocket payment for health services by people of Kurdistan in 2010. Sci J Kurdistan Univ Med Sci. 2013;18(3):20-8.

33. Keshavarz A, Kalhor R, Javadi A, Asefzadeh S. Estimating Out of Pocket payments (oop) for medical cares in Qazvin province in 2009. Hospital quarterly. 2011;10(4):71-7.

34. Semnani S, Keshtkar AA. Assessing of equality on health care cost in Gorgan population laboratory study. J Gorgan Uni Med Sci. 2003;5(2):53-9.

35. Hassan Nejad N. Determining the Methods of Financing Health care Costs among Hospitalized Diabetic Patients in Different Types of Insurances. hospital quarterly. 2012;12(3):83-90.

36. Meskarpour-Amiri M, Assari Arani A, Sadeghi H, AgheliKohnehshahri L. Socioeconomic Factors Affecting Informal Payments in the Health Sector. Transylvanian Rev Adm Sci. 2016:13.

37. Khodamoradi A, Rashidian A, Aghlmand S, Arab M, Moini M. Informal Payments and its Related Factors in Urmia Hospitals. Hakim Health Sys Res. 2015;17(4):313- 21

38. Sun X, Jackson S, Carmichael G, Sleigh AC. Catastrophic medical payment and financial protection in rural China: evidence from the New Cooperative Medical Scheme in Shandong Province. Health economics. 2009;18(1):103-19.

39. Darith D, Tung R, Loun M, Hong R, Barrère B, Fishel J, Reinis K, Wilson-Williams L, Kothari M, Mao B. Cambodia Demographic and Health Survey. National Institute of Statistics, Directorate General for Health, Ministry of Planning Phnom Penh, Cambodia. September 2011. Available from: http://www.unicef.org/cambodia/Cambodia_ DHS 2010 Complete Report Part1.pdf

40. Van Minh H, Kim Phuong NT, Saksena P, James CD, Xu K. Financial burden of household out-of pocket health expenditure in Viet Nam: findings from the National Living Standard Survey 2002-2010. Soc Sci Med (1982). 2013;96:258-63.

41. Pay for health service, WHO. Fact sheets, number 320/ social health protection, February 2007.

42. Moradi-Lakeh M, Vosoogh-Moghaddam A. Health Sector Evolution Plan in Iran; Equity and Sustainability Concerns: Int J Health Policy Manag. 2015 Oct;4(10):637-40. doi:10.15171/ijhpm.2015.160.

43. Health Sector Evolution. Tehran: Ministry of Health and Medical Education, 2015: http://tahavol.behdasht.gov.ir/.

44. Piroozi B, Moradi G, Esmail Nasab N, Ghasri H, Farshadi S, Farhadifar F. Evaluating the effect of health sector evolution plan on cesarean rate and the average costs paid by mothers: A case study in Kurdistan province between 2013-2015. Hayat. 2016;22(3):245-54.

45. Heydarian N, Shaghaeg V. The impact of implantation of Health Care reform plan in patients pay out of pocket in selected Public hospitals in Isfahan. J Med Council Iran. 2015;33(3):187-94.

46. Sarkhanlou F, Saeedi M, Janbabai G, Nikfar S, Morteza-Semnani K, Zaboli P. Comparative Study of Direct Patient and Drug Costs before and after the Implication of Healthcare Reform Program in Sari, Iran. J Mazandaran Univ Med Sci. 2016;26(142):228-32.

47. Liaropoulos L, Siskou O, Kaitelidou D, Theodorou M, Katostaras T. Informal payments in public hospitals in Greece. Health policy (Amsterdam, Netherlands). 2008;87(1):72-81.

48. Ozgen H, Sahin B, Belli P, Tatar M, Berman P. Predictors of informal health payments: the example from Turkey. J Med Syst. 2010;34(3):387-96.

49. Rezapour A, Ebadifard Azar A, Asadi S, Bagheri Faradonbeh S, Toofan F. Estimating the Odd-Ratio of Factors Affecting 
Households' Exposure to Catastrophic and Impoverishing Health Expenditures. J Mil Med. 2016; 18 (1) :355-361

50. Kankeu HT, Boyer S, Fodjo Toukam R, Abu-Zaineh M. How do supply-side factors influence informal payments for healthcare? The case of HIV patients in Cameroon. Int J Health Plann Manage. 2016;31(1):E41-57.

51. Gordeev VS, Pavlova M, Groot W. Informal payments for health care services in Russia: old issue in new realities. Health Econ Policy Law. 2014;9(1):25-48.

52. Rezapour A, Ebadifard Azar F, Azami Aghdash S, Tanoomand A, Hosseini Shokouh SM, Yousefzadeh N, et al. Measuring equity in household's health care payments (Tehran-Iran 2013): technical points for health policy decision makers. Med J Islam Repub Iran. 2015;29:246

53. Baji P, Pavlova M, Gulacsi L, Zsofia HC, Groot W. Informal payments for healthcare services and short-term effects of the introduction of visit fee on these payments in Hungary. Int J Health Plann Manage. 2012;27(1):63-79. 